American Journal of Agricultural and Biological Sciences 5 (2): 183-188, 2010

ISSN 1557-4989

(C) 2010 Science Publications

\title{
Ant Diversity in a Sugarcane Culture without the Use of Straw Burning in Southeast, São Paulo, Brazil
}

\author{
${ }^{1}$ Débora Rodrigues de Souza, ${ }^{2}$ Erich Stingel, ${ }^{2}$ Luiz Carlos de Almeida, \\ ${ }^{1}$ Catarina Bortoli Munhae, ${ }^{4}$ Antonio J. Mayhé-Nunes, \\ ${ }^{3}$ Odair Correa Bueno and ${ }^{1}$ Maria Santina de Castro Morini \\ ${ }^{1}$ Nucleus of Enviornmental Science, Laboratory of Myrmecology, University of Mogi das Cruzes, \\ Avenue Dr. Cândido Xavier de Almeida e Souza, 200, Mogi das Cruzes, Zip Code: 08701-970, SP, Brazil \\ ${ }^{2}$ Center of Sugarcane Technology, Piracicaba/São Paulo, Brazil \\ ${ }^{3}$ Institute of Biosciences, Centro for the study of Social Insects, UNESP, University Estadual Paulista, \\ Avenue $24 \mathrm{~A} \mathrm{n}^{0}$ 1515, Rio Claro, P. O. Box 0199, Zip Code: 13.506-725, SP, Brazil \\ ${ }^{4}$ Department of Animal Biology, Federal Rural University of Rio de Janeiro, \\ Rio de Janeiro, Zip Code: 23890-971, CP 74.514, RJ, Brazil
}

\begin{abstract}
Problem statement: One of the current requirements of agroecosystem management is the maintenance of biodiversity. Manual sugarcane harvesting with the previous burning of straw has been gradually replaced by mechanical harvesting in Brazil. However, the diversity of Formicidae, which can be a natural pest controller, has not been studied in this new system yet. Approach: This study was carried out to assess the diversity of ants in an exclusively mechanically harvested sugarcane culture based on the hypothesis that species richness and abundance will increase with the deposition of straw in this culture system. Ants were sampled using pitfall traps in six sugarcane cultivars during three consecutive harvest cycles. Results: A total of 8,139 ants, distributed in 39 species, were collected. Richness, abundance and diversity differed between harvest cycles, especially in the first cycle, when the soil did not have any straw and in the two last cycles and the straw layer was about $10-15 \mathrm{~cm}$ thick. The communities found in the second and third cycles were similar and the maintenance of straw in the culture contributed to a greater species diversity, particularly of generalist predaceous taxa, which may contribute to the natural control of pests. Conclusion: The diversity of ants increased with straw deposition, including of taxa that may be beneficial to the sugarcane culture. However, new studies of the predatory and competition relations in this agroecosystem are necessary.
\end{abstract}

Key words: Saccharum officinarum, community, richness, abundance, taxa, predators

\section{INTRODUCTION}

Saccharum officinarum L. is a grass native of Southeast Asia. Its culture area of 7 million ha makes Brazil its largest producer and the second largest producer of ethanol in the world (CONAB, 2009; Institute of Agro-industrial Development, 1998; UNICA, 2009).

Presently, ethanol is used as an alternative vehicle fuel in Brazil and the interest of the external market has grown (Corbi and Trivinho-Strixino, 2008). The high productivity, quality and competitiveness of sugarcane cultures require planning and technological changes, besides maintenance of the socio-economical development, rational exploitation and the preservation of the environment. To this end and due to the innumerous negative effects on the environment, especially on insects, manual harvesting and burning have been gradually replaced by mechanical harvesting (Araujo et al., 2005).

Despite the low richness of ants in culture areas (Adams et al., 1981; Risch and Carroll, 1982) they play an important role in these ecosystems, including as biological indicators of edaphic conditions (Lobry de Bruyn 1999; Morris et al., 1999; Peck et al., 1998; Philpott and Armbrecht, 2006; Philpott et al., 2008; Santos et al. 2007) and as pest controllers (Fernandes et al., 1994; Ibarra-Núnez et al., 2001). In soil, they contribute to

Corresponding Author: Maria Santina de Castro Morini, Nucleus of Enviornmental Science, Laboratory of Myrmecology, University of Mogi das Cruzes, Avenue Dr. Cândido Xavier de Almeida e Souza, 200,

Mogi das Cruzes, Zip Code: 08701-970, SP, Brazil Tel: +55-11-47987313 
water infiltration, aeration (Agosti et al., 2000; Hölldobler and Wilson, 1990; 1995), mineralization (Gunadi and Verhoef, 1993) and they stimulate the action of bacteria that contribute to increase soil fertility (Petal et al., 1977).

Based on the ecological importance of Formicidae and the fact that agrosystem management is fundamental for the preservation and maintenance of biodiversity (Dias et al., 2008), this study aimed to study their biodiversity in sugarcane cultures with exclusively mechanical harvesting and test the hypothesis that maintenance of straw in the culture increases the number of species and specimens of ants.

\section{MATERIALS AND METHODS}

Area of study: This study was performed in the municipality of Paraguaçu Paulista $\left(22^{\circ} 24^{\prime} 46^{\prime \prime}\right.$; $50^{\circ} 34^{\prime}$ $33 \mathrm{WW}$ ) in six sugarcane culture areas grown with cultivar SP81-3250. Each sampling site was prepared before the implementation of the sugarcane culture by conventional techniques, surface soil revolving and fertilization at plantation. Management routines and harvest procedures were used during the experimental phase.

Ant sampling: Ants were collected from May 2005 to August 2008, a period corresponding to three harvest cycles of a commercial culture. During the 1st cycle (I), the soil surface did not have any straw, in the 2 nd cycle (II), it had a layer of approximately $10 \mathrm{~cm}$ and in the 3rd cycle (III), the layer was about $15 \mathrm{~cm}$ thick. A 1 ha parcel was chosen in each area for the placement of six pitfall traps measuring $8 \mathrm{~cm}$ high and $9 \mathrm{~cm}$ in diameter, each containing $500 \mathrm{~mL}$ water plus $25 \mathrm{~g}$ of salt and two drops of neutral detergent. The traps were places $30 \mathrm{~m}$ away from each other. The sampling sites were the same in the three sampling periods and the traps were left in the field for 7 days. The collected ants were preserved in $70 \%$ alcohol.

The material was initially identified by genera and morphospecies. The species were identified by comparison with the collection of the Zoology Museum of the University of São Paulo and the pertinent literature. Classification was performed according to Bolton et al. (2006) and voucher specimens were deposited at the University of Mogi das Cruzes (SP).

Data analysis: For the data analysis, richness was defined as the number of species and abundance, as the number of collected individuals per culture cycle. The relative frequency of occurrence was determined based on the total number of records of each species in each cycle using presence/absence data. Shannon's indexes of biodiversity and evenness were calculated with software Biodap (Thomas, 2000). The hypothesis that ant richness and abundance are related to the maintenance of straw in the culture was tested using the Kruskal-Wallis and the Dunn test (Ayres et al., 2007). A matrix with the sum of the records of all species in each of the cycles was used to plot a dissimilarity dendogram based on the Bray-Curtis distance index (Legendre and Legendre, 1998) using software R. The sample effort was analyzed using species accumulation curves. The richness estimation curves were plotted with EstimatesS version 8.0 (Colwell, 2007).

\section{RESULTS}

A total of 39 ant species were collected $(8,139$ specimens), nine (266 workers) in cycle I, 23 (2,808 workers) in cycle II and 21 (5,065 workers) in cycle III. The accumulation curves did not reach the asymptote level (Fig. 1), indicating that the sampling effort was not sufficient to represent the communities in each cycle. The estimated number of species was 23.58 in cycle I, 33.94 in cycle II and 35.58 in cycle III.

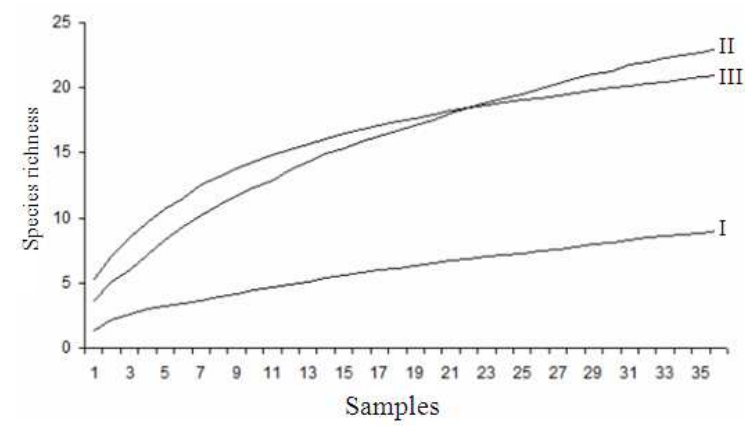

Fig. 1: Curves of accumulation of species for three sugarcane harvest cycles

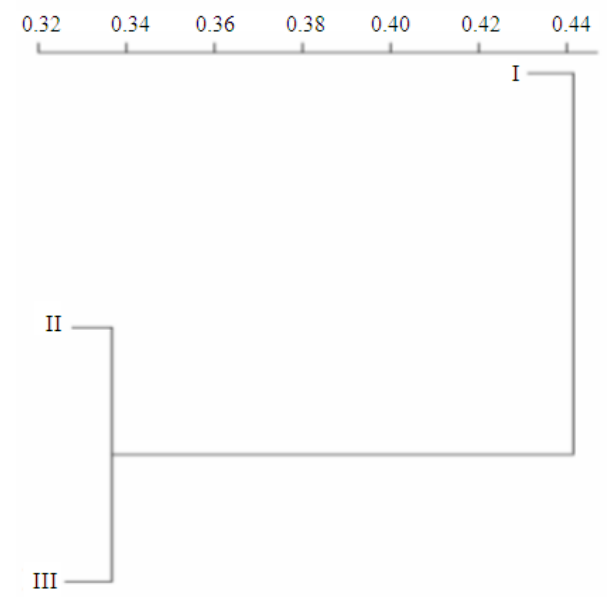

Fig. 2: Dendogram of ant communities sampled during three sugarcane harvest cycles based on the bray-curtis dissimilarity index 
Am. J. Agri. \& Biol. Sci., 5 (2): 183-188, 2010

Table 1: Relative Frequencies of Occurrence (RFO\%) and Abundance (RFA\%) of the species collected during three sugarcane harvest cycles

\begin{tabular}{|c|c|c|c|c|c|c|}
\hline \multirow[b]{3}{*}{ Taxa } & \multicolumn{6}{|l|}{ Cycles } \\
\hline & \multicolumn{2}{|l|}{$\mathrm{I}(\%)$} & \multicolumn{2}{|l|}{ II $(\%)$} & \multicolumn{2}{|l|}{ III $(\%)$} \\
\hline & RFO & RFA & RFO & RFA & RFO & RFA \\
\hline \multicolumn{7}{|l|}{ Dolichoderinae } \\
\hline Dorymyrmex sp.1 & 45.28 & 69.17 & 28.35 & 48.43 & 17.91 & 36.76 \\
\hline Linepithema iniquum (Mayr) & - & - & 0.79 & 0.04 & - & - \\
\hline \multicolumn{7}{|l|}{ Ectatomminae } \\
\hline Ectatomma tuberculatum (Olivier, 1791) & - & - & 1.57 & 0.07 & 0.05 & 0.02 \\
\hline Gnamptogenys striatula (Mayr, 1883) & - & - & - & - & 1.49 & 0.06 \\
\hline \multicolumn{7}{|l|}{ Formicinae } \\
\hline Brachymyrmex incisus (Forel, 1912) & 1.89 & 1.13 & 7.87 & 2.28 & 15.42 & 6.44 \\
\hline Camponotus rufipes (Fabricius, 1775) & - & - & - & - & 1.49 & 0.06 \\
\hline Camponotus sp.4 & - & - & - & - & 1.49 & 0.06 \\
\hline Camponotus sp. 8 & - & - & 0.79 & 0.04 & - & - \\
\hline Camponotus sp.11 & - & - & 3.15 & 1.39 & - & - \\
\hline \multicolumn{7}{|l|}{ Myrmicinae } \\
\hline Acromyrmex niger (Fr. Smith, 1858) & - & - & 3.15 & 0.21 & - & - \\
\hline Apterostigma sp. 2 & - & - & - & - & 3.98 & 0.61 \\
\hline Atta sexdens (Linnaeus, 1758) & - & - & 2.36 & 1.78 & - & - \\
\hline Mycocepurus $\mathrm{sp} .1$ & - & - & - & - & 0.50 & 0.04 \\
\hline Trachymyrmex urichi (Forel, 1893) & 1.89 & 0.38 & 0.79 & 0.39 & - & - \\
\hline Crematogaster (Orthocrema) & - & - & 0.79 & 0.04 & - & - \\
\hline Crematogaster $\mathrm{sp} .5$ & 1.89 & 1.50 & - & - & - & - \\
\hline Crematogaster $\mathrm{sp} .7$ & - & - & - & - & 3.48 & 0.53 \\
\hline Pheidole sp.2 & - & - & - & - & 0.50 & 0.04 \\
\hline Pheidole sp.4 & - & - & 4.72 & 1.28 & 11.44 & 3.36 \\
\hline Pheidole sp.6 & - & - & - & - & 2.49 & 0.14 \\
\hline Pheidole sp.20 & - & - & 1.57 & 0.68 & - & - \\
\hline Pheidole sp.21 & - & - & - & - & 0.50 & 0.02 \\
\hline Pheidole sp.22 & 1.89 & 0.75 & - & - & 2.99 & 1.95 \\
\hline Pheidole sp.27 & - & - & 2.36 & 0.89 & - & - \\
\hline Pheidole sp.28 & - & - & - & - & 0.50 & 0.02 \\
\hline Pheidole sp.34 & - & - & - & - & 7.46 & 1.13 \\
\hline Pheidole sp.35 & 37.74 & 25.19 & 28.35 & 38.75 & 17.91 & 47.92 \\
\hline Pheidole sp.45 & - & - & 0.79 & 0.11 & 2.49 & 0.49 \\
\hline Solenopsis saevissima (Smith) & - & - & - & - & 1.49 & 0.06 \\
\hline Solenopsis (Diplorhoptrum) sp.2 & - & - & 0.79 & 2.10 & - & - \\
\hline Strumigenys elongata (Roger, 1863) & - & - & 0.79 & 2.10 & - & - \\
\hline \multicolumn{7}{|l|}{ Ponerinae } \\
\hline Anochetus sp.2 & - & - & - & - & 5.47 & 0.30 \\
\hline Hypoponera sp.2 & - & - & 0.79 & 0.04 & - & - \\
\hline Hypoponera sp.4 & 1.89 & 0.38 & - & - & - & - \\
\hline Odontomachus affinis (Guerin, 1845) & - & - & 2.36 & 0.11 & 0.50 & 0.02 \\
\hline Odontomachus meinerti (Forel, 1905) & 5.28 & 1.13 & 0.79 & 0.04 & - & - \\
\hline Odontomachus chelifer (Latreille, 1802) & 1.89 & 0.38 & 1.57 & 0.14 & - & - \\
\hline Pachycondyla striata (Fr. Smith, 1858) & - & - & 4.72 & 1.14 & - & - \\
\hline Pachycondyla harpax (Fabricius, 1804) & - & - & 0.79 & 0.04 & - & - \\
\hline Richness per cycle & \multicolumn{2}{|c|}{9.000} & \multicolumn{2}{|c|}{23.000} & \multicolumn{2}{|c|}{21.000} \\
\hline Abundance per cycle & \multicolumn{2}{|c|}{266.000} & \multicolumn{2}{|c|}{2.808} & \multicolumn{2}{|c|}{5.065} \\
\hline Total richness & \multicolumn{2}{|c|}{39.000} & & & \\
\hline Total abundance & \multicolumn{2}{|c|}{8.139} & & & & \\
\hline Diversity index & & & & & & \\
\hline Evenness & & & & & & \\
\hline
\end{tabular}

Richness was significantly different between cycles (Kruskal-Wallis $=57.6203, \quad \mathrm{df}=2, \quad \mathrm{p}<0.05, \mathrm{I} X \mathrm{II}: \mathrm{Z}$ $=6.4963, \mathrm{p}<0.05$ and I X III: $Z=6.6487, \mathrm{p}<0.05)$. A similar result was observed for abundance (KruskalWallis $=10.4116$, df $=2, p<0.05 ; \quad$ I X II: $Z=6.4963$, $\mathrm{p}<0.05$ and I X III: $Z=2.8043, \mathrm{p}<0.05)$. The diversity index was significantly different between cycles
(Kruskal-Wallis $=8.8570, \quad \mathrm{df}=2, \mathrm{p}<0.05 ; \quad$ I X III: $\mathrm{Z}=$ $2.8118, \mathrm{p}<0.05)$, the evenness values indicate that the species that composed the ant communities in cycles II and III have similar representations (Table 1). These values corroborate the Bray-Curtis distance index (Fig. 2).

Myrmicinae was the richest subfamily (22 species), followed by Ponerinae ( 8 species) and Formicinae (5 
species). In the three cycles, the most frequent and abundant species were the same, Dorymyrmex sp.1 and Pheidole sp. 35 (Table 1) and most of the species that were sampled were generalists.

\section{DISCUSSION}

Mulching in extensive sugarcane culture may contribute to the action of decomposers that increase the availability of resources in the environment by actively recycling several organic compounds (Gonzalez and Seastedt, 2000), such as sugars, amino acids, waxes, phenols, lignins and acids (Shinitzer, 1991), thus allowing the coexistence of a greater number of species in the same habitat. The presence of straw affords greater richness, abundance and diversity to the ant community in relation to the culture without mulching, or even when compared to the culture with manual harvest and straw burning (Rossi and Fowler, 2004).

However, no significant difference was observed in richness, abundance and diversity after mulching, even with the accumulation of organic matter between cycles. In tropical forest areas, the amount of litter influences species richness, as ants find more food resources and nesting places and a microclimate more favorable to their requirements (Andersen, 1983; Armbrech et al., 2004; Campos et al., 2003; Carvalho and Vasconcelos, 1999; Kaspari and Weiser, 2000; Philpot and Foster, 2005). More recent studies acknowledge that the base of the trophic in the litter are fungi, bacteria and chemical elements and all are particularly important to increase the diversity of the ant fauna (Kaspari et al., 2008; Mcglyn and Salinas, 2007; Mcglyn et al., 2009). Thus, the resources produced by these interactions in the straw layer between Cycles II and III probably become available in a similar way.

In cycle I, most of the species are generalist and can exploit a large variety of environmental resources (Brown, 2000). In the subsequent cycles, besides generalist species, there are also some fungus-growing species, such as Apterostigma and Mycocepurus, which use insect feces, dead insects and cellulosic material as substrates (Hölldobler and Wilson, 1995) and also cryptic and specialized predaceous species, such as Hypoponera, Odontomachus, Ectatomma, Gnamptogenys, Anochetus, Pachycondyla and Strumigenys (Delabie et al., 2000), which often are absent in disturbed environments (Underwood and Fisher, 2006).

In comparison to generalist taxa, Pheidole is richer between harvest cycles. This genus is important for the control of several agroecosystem pests, as it can predate on eggs and immature stages of other insects (Fernandes et al., 1994; Rossi and Fowler, 2000; Way and Khoo, 1992). In contrast, the frequency, occurrence and abundance of Odontomachus and Dorymyrmex decreased between cycles and those of Brachymyrmex incisus Forel, 1912, Pheidole sp.35 and Solenopsis saevissima F. Smith increased. The presence of straw probably did not favor the survival of some species due to abiotic changes in the environment, or even due to the presence of competitive taxa, as is the case with Solenopsis (Delabie and Fowler, 1995) and Pheidole (Fowler et al., 1993). As an example, Dorymyrmex is negatively associated with Pheidole and Brachymyrmex (Kamura et al., 2007) in urban areas. The same may happen in the studied agroecosystem. One of the aggravating factors of this association may be the long term increase in Diatraea saccharalis (Fabr.), a major sugarcane pest (Beuzelin et al., 2009; Pinheiro et al., 2008), as Dorymyrmex is one of its predators (Rossi and Fowler, 2004).

In general, straw enables the presence of generalist predaceous taxa that may contribute to the natural biological control (Fernandes et al., 1994; Risch and Carroll, 1982), such as Ectatomma, which predates about $89.9 \%$ of the pests, including leaf-cutting ants, in coffee culture (Ibarra-Núnez et al., 2001) or Crematogaster, Pheidole and Solenopsis, in sugarcane culture (Rossi and Fowler, 2004).

\section{CONCLUSION}

The analyzed ecological variables had a lower magnitude in the first sugarcane cycle, when the soil had no cover. The presence of generalist taxa that predate on several culture pests was also noticeable in the second and third cycles. However, as mechanical harvesting is a recent management practice, studies that demonstrate the diversity of the agroecosystem as a whole and the possible competition and predation relations between the communities are necessary to better evaluate the possible benefits of mulching on the soil for the culture.

\section{ACKNOWLEDGMENT}

The researchers thanks $\mathrm{CNPq}$ for a scientific initiation scholarship granted to the first author and to FAEP/UMC for the financial support.

\section{REFERENCES}

Adams, C.T., T.E. Summers, C.S. Lofgren, D.A. Focks and J.C. Prewitt, 1981. Interrelationship of ants and the sugarcane borer in Florida sugarcane fields. Environ. Entomol., 10: 415-418. 
Agosti, D., J.D. Majer, L.E. Alonso and T.R. Schultz, 2000. Ants: Standard Methods for Measuring and Monitoring Biodiversity. Smithsonian Institution Press, Washington DC., ISBN: 1-56098-858-4, pp: 280.

Andersen, A.N., 1983. Species diversity and temporal distribution of ants in the semi-arid mallee region of northwestern Victoria. Aust. J. Ecol., 8: 127-37. http://www3.interscience.wiley.com/journal/11955 2562/abstract?CRETRY $=1 \&$ SRETRY $=0$

Araujo, R.A., M.S. Araújo, A.H.R. Gonring and R.N.C. Guedes, 2005. Impacto da queima controlada da palhada da cana de açúcar sobre as comunidades de insetos locais. Neotropic. Entomol., 34: 649-658. DOI: 10.1590/S1519566X2005000400016

Armbrech, I., I. Perfecto and J. Vandermeer, 2004. Responds to diverse resources enigmatic biodiversity correlations: Ant diversity. Science, 304: 284-286. DOI: 10.1126/science.1094981

Ayres, M., M. Ayres Jr., D.L. Ayres and A.S. Dos Santos, 2007. BioEstat 5.0: Stats applications in the áreas of Biological Sciences and Medical. 5nd Edn., Institute for Sustainable development Mamirauá. IDSM/MCT/CNPq, pp: 364.

Beuzelin, J.M., T.E. Reagan, W. Akbar, H.J. Cormier, J.W. Flanagan and D.C. Blouind, 2009. Impact of hurricane rita storm surge on sugarcane borer (Lepidoptera: Crambidae) management in Louisiana. J. Econ. Entomol., 102: 1054-1061. DOI: 10.1603/029.102.0325

Bolton, B., G. Alpert, P.S. Ward and P. Naskreccki, 2006. Bolton's Catalogue of Ants of the World. Harvard University Press, Cambridge, pp: 1758-2005.

Brown, Jr., W.L., 2000. Diversity Ants. In: Ants: Standard Methods for Measuring And Monitoring Biodiversity. Donati Agosti, Jonatham. D. Majer, Leeanne E. Alonso and T.R. Schultz (Eds.). Smithsonian Institution Press, Washington DC., ISBN 1-56098-858-4, pp: 45-79.

Campos, R.F., J.H. Shoereder and C.F. Sperber, 2003. Local determinants of species richness in litter ant communities (Hymenoptera: Formicidae) Sociobiology, 41: 357-367. http://cat.inist.fr/?aModele $=$ afficheN\&cpsidt $=1450$ 2499

Carvalho, K.S. and H.L. Vasconcelos, 1999. Forest fragmentation in central Amazonia and its effects on litter-dweling ants. Biol. Cons., 91:151-157. DOI: 10.1016/S0006-3207(99)00079-8

Colwell, R.K., 2007. Estimates: Statistical estimation of species richness and shared species from sample. Version 8.0 User's guide and application. http://viceroy.ceb.uconn.ed/EstimateS
CONAB., 2009. National Supply Company. http://www.conab.gov.br

Corbi, J.J. and S. Trivinho-Strixino, 2008. Relationship between sugar cane cultivation and stream macroinvertebrate communities: A study developed in the southeast of Brazil. Braz. Arch. Biol. Technol., 51: 769-779. http://www.scielo.br/pdf/babt/v51n4/v51n4a15.pdf

Delabie, J.H. and H.G. Fowler, 1995. Soil and litter cryptic ant assemblages of Bahian cocoa plantations. Pedobiologia, 39: 423-433.

Delabie, R.K., D. Agosti and I.C. Nascimento, 2000. Litter ant Communities of the Brazilian Atlantic Raim Forest Region. In: Sampling GroundDweling Ants: Case Studies from World's Rain Forest, Agosti, D., J. Majer, L. Alonso and T. Schultz, (Eds.). pp: 1-17.

Dias, N.S., R. Zanetti, M.S. Santos, J. Louzada and J.H. Delabie, 2008. Interaction of forest fragments with adjacent coffe agroecoystems and grasslands: responses of ant communities (Hymenoptera: Formicidae). Iheringia Serie Zool., 98: 136-146.

Fernandes, W.D., P.S. Oliveira, S.L. Carvalho and M.E.M. Habib, 1994. Pheidole ants as potencial biological control agents of the boll weevil, Anthonomus grandis (Coleoptera: Curculionidae) in Brazil. J. Applied Ecol., 18: 437-441.

Fowler, H.G., F. Anaruma-Filho and O.C. Bueno, 1993. Seasonal space usage by the introduced pharaoh's ant Monomorium pharaonis (L.) (Hymenoptera: Formicidae), in institucional settings in Brazil and its relation to other structural ant species. J. Applied Entomol., 115: 416-419.

Gonzalez, G. and T.R. Seastedt, 2000. A comparison of the abundance and composition of litter fauna in tropical and subalpine forests. Pedobiologia, 44: 545-555. DOI: 10.1078/S0031-4056(04)70070-0

Gunadi, B. and H.A. Verhoef, 1993. The flow of nutrients in a Pinus merkusii forest plantation in Central Java: The contribution of soil animals. Eur. J. Soil Biol., 29: 133-139.

Hölldobler, B. and E.O. Wilson, 1990. The Ants. Belknap Press, Cambridge, Massachusetts.

Hölldobler, B. and E.O. Wilson, 1995. Journey to the Ants: A Story of Scientific Exploration. 2nd Edn., Belknap Press, Cambridge, Massachusetts, ISBN: 0674485262, pp: 228.

Ibarra-Núnez, G., J.A. Garcia, J.A. López and J.P. Lachaud, 2001. Prey analysis in the diet of some ponerine ants (Hymenoptera: Formicidae) and web-building spiders (Araneae) in coffee plantations in Chiapas, Mexico. Sociobiology, 37: 723-755. 
Institute of Agro-industrial Development. 1998. Performance Indicators for the Sugarcane IndustryHarvest/97/98. IDEA, Ribeirão Preto, pp: 116.

Kamura, C.M., M.S.C. Morini, C.J. Figueiredo, O.C. Bueno and A.E.C. Campos-Farinha, 2007. Ant communities (Hymenoptera: Formicidae) in an urban ecosystem near the Atlantic rainforest. Braz. J. Biol., 67: 635-641. DOI: 10.1590/S007347212007000300005

Kaspari, M. and M.D. Weiser, 2000. Ant activity along moisture gradients in a Neotropical forest. Biotropica, 32: 703-711.

Kaspari, M., S.P. Yanoviak and R. Dudley, 2008. On the biogeography of salt limitation: A study of ant communities. PNAS, 105: 17848-17851. http://faculty-staff.ou.edu/K/Michael.E.Kaspari1/PDF_reprints/Kaspari_2008_PNASsalt.pdf

Legendre, P. and L. Legendre, 1998. Numerical Ecology. 2nd Edn., Elsevier Press, Amsterdam, ISBN: 0444 892508, pp: 851.

Lobry de Bruyn, L.A., 1999. Ants as bioindicators of soil function in rural environments. Agric. Ecosyst. Environ., 74: 425-441. DOI: 10.1016/S01678809(99)00047-X

Mcglyn, T.P. and D.J. Salinas, 2007. Phosphorus limits tropical rain forest litter fauna. Biotropica, 39: $50-53$.

Mcglyn, T.P., R.M. Fawcett and D.A. Clark, 2009. Litter biomass and nutrient determinants of ant diversity, nest size and growth in a Costa Rica tropical wet forest. Biotropica, 41: 234-240. http://www.leaflitter.org/documents/2009McGlynn BiotropicaLitterandNutrientDeterminants.pdf

Morris, T.I., M. Campos, N.A.C. Kidd, M.A. Jervis and W.O.C. Symondson, 1999. Dynamics of the predatory arthropod community in Spanish olive groves. Agron. Forest Entomol., 1: 219-228. http://www3.interscience.wiley.com/journal/11909 0859/abstract

Peck, S.L., B. McQuaid and C.L. Campbell, 1998. Using ant species (Hymenoptera: Formicidae) as a biological indicator of agroecosystem condition. Environ. $\quad$ Entomol., 27: 1102-1110. http://www.entsoc.org/pubs/periodicals/ee/eetocs/P DF/en059801102.pdf

Petal, J., E. Nowak, H. Jakubczyk and Z. Czerwinski, 1977. Effect of ants and earthworms on soil habitat modification. Ecol. Bull., 25: 501-503. http://www.jstor.org/stable/20112621

Philpot, S.M. and P.F. Foster, 2005. Nest-site limitation in coffee agroecosystems: Artificial nests maintain diversity of arboreal ants. Ecol. Appli., 15: $1478-1485$.
Philpott, S.M. and I. Armbrecht, 2006. Biodiversity in tropical agroforests and the ecological role of ants and ant diversity in predatory function. Ecol. Entomol., 31: 369-377. DOI: 10.1111/j.13652311.2006.00793.x

Philpott, S.M., I. Perfecto and J. Vandermeer, 2008. Effects of predatory ants on lower trophic levels across a gradient of coffee management complexity. J. Animal Ecol., 77: 505-511. DOI: 10.1111/j.1365-2656.2008.01358.x

Pinheiro, D.O., I. Quagio-Grassiotto and E.A. Gregório, 2008. Morphological regional differences of epithelial cells along the midgut in Diatraea saccharalis Fabricius (Lepidoptera: Crambidae) larvae. Neotropic. Entomol., 37: 413-419. DOI: 10.1590/S1519-566X2008000400009

Risch, S. and R.C. Carroll, 1982. The ecological role of ants in two Mexican agroecosystems. Oecologia, 55: 114-119. DOI: 10.1007/BF00386726

Rossi, M.N. and H.G. Fowler, 2000. Ant predation of larval Diatraea saccharalis Fab. (Le., Crambidae) in new sugarcane in Brazil. J. Applied Entomol., 124: 245-247.

Rossi, M.N. and H.G. Fowler, 2004. Predaceous at fauna in new sugarcane fields in the state of São Paulo, Brazil. Braz. Arch. Biol. Technol. Int. J., 47: 805-811. DOI: $10.1590 /$ S151689132004000500017

Santos, A.P., J.E. Cabanas and J.A. Pereira, 2007. Abundance and diversity of soil in olive grove ecosystem (Portugal): Effect of pifall trap type. Eur. J. Soil Biol., 43: 77-83. DOI: 10.1016/j.ejsobi.2006.10.001

Shinitzer, M., 1991. Soil organic matter: The next 75 years. Soil Sci., 151: 41-58. http://journals.lww.com/soilsci/Abstract/1991/0100 0/Soil_Organic_Matter_the_Next_75_Years.8.aspx

Thomas, G.M., 2000. A biodiversity analysis package. BioDap. http//nhsbig.inhs.uiuc.edu/www/populations/biodap_readme.html/

Underwood, E.C. and B.L. Fisher, 2006. The role of ants in conservation monitoring: If when and how. Rev. Biol. Conserv., 132: 166-182. DOI: 10.1016/j.biocon.2006.03.022

UNICA., 2009. Union's sugarcane industry in São Paulo. http://www.unica.com.br

Way, M.J. and K.C. Khoo, 1992. Role of ants in pest management. Ann. Rev. Entomol., 37: 479-503. http://arjournals.annualreviews.org/doi/pdf/10.1146 /annurev.en.37.010192.002403 